DOI 10.18551/rjoas.2021-08.15

\title{
ADOPTION OF ORGANIC AGRICULTURE APPLICATION IN SUBANG REGENCY, WEST JAVA PROVINCE OF INDONESIA
}

\author{
Marnata S. Opin Adelpho \\ Business School, IPB University, Indonesia \\ Najib Mukhammad* \\ Department of Management, Faculty of Economic and Management, IPB University, \\ Indonesia \\ Purnaningsih Ninuk \\ Department of Communication and Community Development, Faculty of Human Ecology, \\ IPB University, Indonesia \\ *E-mail: mnajib23@yahoo.com
}

\begin{abstract}
Indonesia is one of the countries that has started to develop organic agriculture. The appeal of organic farming, both farmers and ordinary people, is also triggered by consumer awareness of choosing food that is safe for health. This research is a survey research, namely explanatory/confirmatory research. The research was conducted using interview methods and questionnaire instruments. The side method uses purposive sampling. Hypothesis testing showed that the nature of innovation (t-statistic 2.741) and extension support (t-statistical 8.530) had a significant effect on the level of interest of farmers while the nature of prospective users (t-statistical 3.174) and extension support (t-statistical 2.274) had a significant effect on the level of farmer adoption. The conclusion of this research is; (1) Farmers already know and try organic farming, however, the adoption process is still affected by market access which makes farmers still reluctant to start implementing organic farming; (2) the nature of innovation and extension support are factors that affect the level of interest of farmers; The nature of the candidate (characteristics) and counseling are factors that influence adoption; (3) P4S Agrospora in this case becomes a forum for farmers to learn about the application of organic agriculture but needs to be empowered again for independent extension workers who are able to play the same role as P4S.
\end{abstract}

\section{KEY WORDS}

Agriculture, organic, adoption, innovation.

The role of agriculture in the national economy includes increasing employment, improving people's welfare and also in increasing Gross Domestic Product (GDP). The Ministry of Agriculture (2019) reported that the increase in GDP in the agricultural sector occurred at the beginning of 2019 , where it grew by around 5.41 percent. Food availability is an important aspect in realizing food security because food supply is needed to meet the needs and consumption of food for the community, households and individuals in a sustainable manner. Indonesia is one of the countries that have started to develop organic agriculture. Organic farming is not only limited to minimizing and eliminating the use of synthetic and chemical inputs, but the use of natural resources is carried out in a sustainable manner, saving energy and producing healthy food as well.

The attractiveness of organic farming, both farmers and ordinary people, is also triggered by awareness of the dangers left behind from excessive residue; most consumers will choose food that is safe for health. West Java is a province with 6,944 hectares of organic area located in 22 regencies, one of which is Subang Regency. The Ministry of Agriculture launched that it fully supports in 2019 West Java as the largest producer or producer of organic rice in Indonesia (Ministry of Agriculture, 2019). Subang Regency, 
especially in the village of Pringkasap, has the potential of rice fields covering an area of 627 hectares which is crossed by the East Tarum irrigation and part of the area can be planted three times a year. Along with the development of organic agriculture, especially in Pringkasap Village, there are still many farmers who are reluctant and unwilling to transform from conventional agriculture to organic farming.

The purpose of this study was to analyze the process of farmer adoption of the organic farming system, explore what factors influence the adoption process of farmers in the application of organic farming systems, and determine the role of P4S Agrospora in organic farming adoption in Pabuaran District, Subang Regency, West Java.

\section{METHODS OF RESEARCH}

Research was conducted from April to June 2021. This research is a survey research, namely explanatory research, which is to explain causal relationships and test hypotheses. Exploratory studies are very useful when researchers lack ideas about problems that may arise during the research process. Exploration can also help learn something completely new, where the variables have not been fully explained (Sudirman, 2009).

Determining the number of samples for a small population (less than a thousand) researchers require a large sample comparison, which is about 30 percent of the population. Therefore, the number of samples in this study was around 105 consisting of 54 adopter farmers and 51 non-adopter farmers in order to represent the diversity of population characteristics.

The survey method was conducted using interview techniques and questionnaire instruments. This research also uses descriptive quantitative methods to complement each other in terms of generalizing and strengthening the depth of an issue. The questionnaire was divided into three parts: screening of respondent profiles and related main questions for research variables.

The respondent's profile consists of age, formal education, non-formal education, years of farming, and land ownership status. The scale used is a Likert scale with five levels, namely (1) Strongly disagree, (2) Disagree, (3) Agree, (4) Strongly Agree. Quantitative data as well as data obtained directly from surveys is processed using a simple data tabulation technique which is then processed by PLS analysis using the Smart-PLS 3.0 Version application.

\section{RESULTS OF STUDY}

Pringkasap Village is one of the rice barns in Subang Regency (West Java) which has a very large potential for rice fields with an area of about $627 \mathrm{Ha}$. Most of the people in this village are farmers. Environmentally, Pringkasap Village is crossed by the East Tarum Irrigation so that some of the rice fields are able to produce 3 times in 1 (one) year.

The results of this research survey regarding the indicator variables of the nature of innovation are presented in the table. The lowest mean score is found in the SI12 indicator variable, namely conformity and the percentage of answers agreeing is 38.10 percent. Thus it can be concluded that the majority of respondents are familiar with the application of organic agriculture in Subang district.

Table 1 - Descriptive Characteristics of Innovation

\begin{tabular}{llllll}
\hline Indicators & Average & Strongly Agree (\%) & Agree (\%) & Disagree (\%) & Strongly Disagree (\%) \\
\hline Relative Advantage & 2,613 & 19,05 & 57,14 & 23,81 & 0 \\
Compability & 2,575 & 17,14 & 38,10 & 36,19 & 8,57 \\
Complexity & 2,884 & 7,62 & 35,24 & 19,05 & 38,10 \\
Triabillity & 2,674 & 18,10 & 37,14 & 37,14 & 7,62 \\
Observability & 2,750 & 7,62 & 18,10 & 64,76 & 9,52 \\
\hline
\end{tabular}

The characteristics of internal users of Paguyuban Bumi Mandiri, Pringkasap Village, Pabuaran District are age, formal education, non-formal education, length of business in rice 
farming, land ownership status, and cosmopolitan level (contacts with outside parties). The characteristics above are the characteristics of each of these respondents. The condition of internal characteristics in the pringkasap village is generally at a low level.

Table 2 - Descriptive Characteristics of Prospective Users

\begin{tabular}{|c|c|c|}
\hline Indicators & Frequency & Percentage \\
\hline \multicolumn{3}{|l|}{ Age Group (years) } \\
\hline - Early Adult (18-30) years & 40 & 38,10 \\
\hline - $\quad$ Middle Adult (31-60) years & 56 & 53,33 \\
\hline - Very Mature $(>60)$ years & 9 & 8,57 \\
\hline \multicolumn{3}{|l|}{ Formal Education } \\
\hline - $\quad$ Low (6 years) & 30 & 28,57 \\
\hline - $\quad$ Medium (9 years old) & 67 & 63,81 \\
\hline - $\quad$ High $(10-15$ years old) & 8 & 7,62 \\
\hline \multicolumn{3}{|l|}{ Non-Formal Education } \\
\hline - $\quad$ Very Low (0-3 times) & 20 & 19,05 \\
\hline - $\quad$ Low (4-8 times) & 73 & 69,52 \\
\hline - $\quad H i g h$ (9-15 times) & 12 & 11,43 \\
\hline \multicolumn{3}{|l|}{ Farming Experience } \\
\hline - $\quad$ Low $(0-25$ years $)$ & 76 & 72,38 \\
\hline - $\quad$ High (26-50 years) & 29 & 27,62 \\
\hline \multicolumn{3}{|l|}{ Land Mastery } \\
\hline - $\quad$ Very Low $(0-2 \mathrm{Ha})$ & 40 & 38,10 \\
\hline - $\quad \operatorname{Low}(3-5 \mathrm{Ha})$ & 57 & 54,29 \\
\hline - Height $(6-10 \mathrm{Ha})$ & 8 & 7,62 \\
\hline \multicolumn{3}{|l|}{ Cosmopolitan Level } \\
\hline - Very low (0-5 times) & 53 & 50,48 \\
\hline - $\quad$ Low (6-10 times) & 47 & 44,76 \\
\hline - High (11-15 times) & 5 & 4,76 \\
\hline - Very High (16-20 times) & 0 & 0 \\
\hline
\end{tabular}

Most of the respondents agree with several indicators of extension support. This indicates that the extension support is in accordance with the needs of farmers, whether organic, semi-organic, or conventional. This is supported by research by Asta (2015) which states that extension materials must always meet the needs of farmers. The extension material is quite appropriate to the needs of the farmers, the extension workers are capable enough and the intensity of the extension is quite high.

Table 3 - Descriptive Agricultural Extension Support

\begin{tabular}{llllll}
\hline Indicators & Average & Strongly Agree (\%) & Agree (\%) & Disagree (\%) & Strongly Disagree (\%) \\
\hline Appropriateness Method Extension & 2,271 & 3,81 & 47,62 & 45,71 & 2,86 \\
Compliance Guidance Material & 2,748 & 2,86 & 60,95 & 32,38 & 3,81 \\
Extension Competence & 2,745 & 2,86 & 57,14 & 38,10 & 1,90 \\
Extension Intensity & 2,635 & 5,71 & 47,62 & 43,81 & 2,86 \\
\hline
\end{tabular}

Table 4 - Descriptive Institutional Support

\begin{tabular}{llllll}
\hline Indicators & Average & Strongly Agree (\%) & Agree (\%) & Disagree (\%) & Strongly Disagree (\%) \\
\hline Government Support & 2,124 & 37,14 & 38,10 & 20,00 & 4,76 \\
Farmer's Group Support & 2,705 & 25,71 & 33,33 & 21,90 & 2,86 \\
Market Access & 3,071 & 35,24 & 54,29 & 17,14 & 2,86 \\
Information Support & 3,029 & 0 & 76,19 & 21,90 & 1,90 \\
\hline
\end{tabular}

Saleh et al. (2007) say that institutions are an important factor in regulating relationships between individuals for the mastery of scarce factors of production. Institutions have a strategic role, but according to Soekartawi (2002) institutional aspects, both formal and informal, are the most prominent aspects that can hinder agricultural development in developing countries. This happens because the existing institutions in developing countries, including Indonesia, are still not optimal.

The persuasion stage about organic rice farming system innovation is reflected through interest in organic rice farming innovation, desire to try organic rice farming system and desire to implement organic rice farming. 
Table 5 - Descriptive of Farmers Interest Level

\begin{tabular}{llllll}
\hline Indicators & Average & Strongly Agree (\%) & Agree (\%) & Disagree (\%) & Strongly Disagree (\%) \\
\hline Interest in Organic Rice Innovation & 2,663 & 28,57 & 38,10 & 22,86 & 10,48 \\
Interest to Try & 2,562 & 28,57 & 35,24 & 21,90 & 14,29 \\
Interest to Apply & 2,592 & 22,86 & 44,76 & 17,14 & 15,24 \\
\hline
\end{tabular}

The level of adoption of organic rice farming is reflected by the indicators of the intensity of adoption, and the level of adaptation to organic rice farming. Gunawan (2019) said that this can be understood as the application of organic rice farming to the use of organic fertilizers and eliminating the use of synthetic chemical fertilizers or pesticides. The application is not limited to the use of fertilizers but also the manufacture of organic fertilizers independently.

Table 6 - Descriptive of Farmer Adoption Level

\begin{tabular}{llllll}
\hline Indicators & Average & $\begin{array}{l}\text { Strongly } \\
\text { Agree }(\%)\end{array}$ & Agree (\%) & $\begin{array}{l}\text { Disagree } \\
(\%)\end{array}$ & Strongly Disagree (\%) \\
\hline Intensity Adoption & 2,810 & 17,14 & 38,10 & 27,62 & 17,14 \\
Adoption Level & 2,505 & 14,29 & 42,86 & 32,38 & 20,00 \\
\hline
\end{tabular}

Testing the research hypothesis using the t-statistic coefficient. Where the output of the bootstrapping command produces t-statistics. Indicators that have a t-statistic $>1.96$ are said to be significant (Ghozali and Latan, 2015). An indicator can also be said to be influential if it has a $p$-value $<0.05$ (Haryono, 2017). The stages of testing the structural model (hypothesis testing) are carried out with the following steps:

Table 7 - Hypothesis Test

\begin{tabular}{|c|c|c|c|}
\hline & Standard Deviation (STDEV) & T Statistics (|O/STDEV|) & P Values \\
\hline Innovation Traits > Interest Level of Farmers & 0.066 & 2.741 & 0.006 \\
\hline Traits of Prospective Users > Interest Level of Farmers & 0.059 & 0.246 & 0.806 \\
\hline Extension Support > Farmer Interest Level & 0.069 & 8.530 & 0.000 \\
\hline Institutional Support > Farmer Interest Level & 0.089 & 1.707 & 0.088 \\
\hline Innovation Traits > Farmer Adoption Level & 0.080 & 1.440 & 0.150 \\
\hline Prospective User Traits > Farmer Adoption & 0.055 & 3.174 & 0.002 \\
\hline Agricultural Extension Support > Farmer Adoption & 0.101 & 2.274 & 0.023 \\
\hline Institutional Support > Farmer Adoption & 0.087 & 0.641 & 0.522 \\
\hline Farmer Interest Level -> Adoption Farmer & 0.094 & 6.245 & 0.000 \\
\hline
\end{tabular}

\section{DISCUSSION OF RESULTS}

This research is a study that examines the factors that influence farmers' interest in the application of organic farming in Pabuaran sub-district, Subang district, West Java. Testing the variables using PLS with Smart-PLS version 3.0 Software. There are six latent variables in the study, namely the nature of innovation (X1), the nature of potential users (individual characteristics) (X2), extension support (X3), institutional support (X4), farmers' interest level $(\mathrm{Y} 1)$ and farmer adoption behavior (Y2). Each latent variable has its own indicator variable as described in the research method.

The Influence of the Characteristics of Innovation on Farmers' Interest Level. Variables of the nature of innovation contribute to a large influence on the level of interest and the level of adoption of farmers directly. This means that the better the farmer's perception of organic rice farming innovations, the greater the interest and adoption of organic rice farming innovations, the desire to try and implement organic rice farming. The facts in the field show that most farmers have tried the application of organic rice farming, although they no longer use it due to unsupportive market demand so that the capacity for organic rice yields is difficult. Shelters and processing of organic rice products are also temporarily still relying on P4S Agropora. The results showed that the nature of innovation had a significant effect on the assessment of the relative profit level in the application of organic rice farming. The level of relative profit has an influence on the level of interest of farmers, thus showing a picture of the benefits that farmers get in the application of organic rice farming which affects their 
interest in organic rice farming innovations, the desire to try and implement organic rice farming. Economic advantages are considered by farmers in deciding to implement organic farming.

When viewed from the experimental indicator, the results of the study show that organic rice farming innovations are easy to try on a small scale, especially related to the manufacture of organic fertilizers and the manufacture of vegetable pesticides where previously most farmers already know and make vegetable pesticides that are used from horticultural crops such as shallots and green onions. garlic. Likewise with organic fertilizers whose fulfillment is obtained from natural materials such as animal waste, other organic waste. Gunawan's research (2019) says that the farmers' habit is to try first on a small scale so that the convenience and benefits can be seen directly in the field. The results of this trial will be a consideration for whether the organic rice farming innovation can be continued or not. This is also in accordance with research conducted by Hubbard and Sandmann (2007) which revealed that farmers can carry out new innovative practices at the pilot level, so it is possible that potential practices can be further modified to meet farmers' specific needs.

The Influence of the Characteristics of Prospective Users on Adoption Behavior. Variables of the nature of potential users (characteristics) include age, formal education, nonformal education, area of land tenure, length of farming and the cosmopolitan level of the farmer himself. The description of the indicators of the nature of potential users illustrates that the majority of farmers are in the age range of 31-60 years, formal education is 9 years or in other words a maximum of junior high school (School of Junior High School). This condition explains the lack of maturity of skills and knowledge of the farmers. Gunawan (2019) said that formal education owned by farmers is very important to develop their capacity. The learning process through formal education can be used to improve knowledge, attitudes and skills. This is important because organic farming requires different knowledge, attitudes and skills from conventional farming systems. This is in line with Prawiranegara (2016) and Ruhimat (2014), showing that the higher a person's level of education, the more rational their way of thinking, attitudes and behavior will be in accepting and understanding the technological innovations they obtain.

In addition, the significant effect is the indicator of land tenure on the level of adoption of farmers directly. This means that the wider the land tenure, the greater the interest of farmers in organic rice farming. Extensive land tenure makes farmers have the choice to do farming according to their wishes. Mardikanto in Charina (2018) said that the adoption of innovation is influenced by population variables, characteristics of technology, sources of knowledge, awareness, attitudes and group influence. In addition, Burhansyah (2014) also explains that factors influencing adoption include distance to the location of the farm, distance from technology sources, farmers' income levels, land area and accessibility to technology sources. Zulvera (2014) also adds by mentioning that the level of farmer adoption is related to the knowledge, attitudes, skills and perceptions of farmers about the organic farming system obtained by farmers through the learning process they have gone through.

The Effect of Agricultural Extension Support on Farmer Adoption Behavior. Variables of extension support can be reflected by the four indicators that make it up, namely extension materials, extension methods, extension capabilities and extension intensity. Discussions about counseling, will not be separated from empowerment, where empowerment is the goal of the counseling. Empowerment will produce a dynamic and progressive society in a sustainable manner, because it is based on both intrinsic and extrinsic motivation. The importance of extension in increasing the interest of farmers is shown from the relationship that has a significant effect on the interest of farmers and directly on the level of adoption of farmers. On the indicator of the ability of extension workers to support extension activities, by providing practice of extension materials, motivating farmers to implement innovation and being able to assist farmers in information technology as well as being a window for government programs in supporting programs and activities related to agricultural human resources.

According to van den Ban and Hawkins (1999), extension requires a high capacity of the extension worker with a positive attitude towards farmers. Farmers consider the use of 
extension methods by extension workers to be inappropriate. The counseling method that is often used is face-to-face meetings, in the form of group discussions on farmer's land with pilot plots/ demonstration plots and field schools assessed by respondent farmers as easy to understand. Through demonstration plots and field schools, respondent farmers in this study were able to see the real results of an innovation introduced by the extension worker. Fatchiya (2010) states that direct practice has the potential to increase understanding much higher than just seeing and hearing. This is in accordance with what was stated by Mardikanto (2009) that the demonstration method is often seen as an effective method, where the target of extension is shown by real evidence so that farmers tend to be more quickly encouraged to try and implement the innovations introduced. Most of the farmers considered the extension workers to have good communication skills so that the material presented by the extension workers could be well received by the farmers. Extension activities are not only carried out face-to-face or group meetings, but also assistance in the field. Participatory interactions provide the widest possible space for extension workers and farmers to forge togetherness in encouraging problem-solving abilities (Sumardjo, 1999). Communication between extension workers and farmers is intensified, for example; by increasing extension visits to farmer groups, making additional visits outside the regular schedule of extension activities and extension workers coming from time to time to farmers who are facing problems in their farming business.

The fact in the field is that the extension workers actively participate in the process of farmers knowing the application of organic rice farming, including what is done by self-help extension workers facilitated by P4S Agrospora. The paradigm of self-help extension is participatory extension, no longer one-way extension. Extension workers must be able to live among farmers, be present in the spirit of farmers and be involved in a participatory manner in farmer activities. Syahyuti (2014) said that self-help extension workers in this case become a complete figure, this type of extension performs extension activities with social motivation, service as well as business. In addition to participation, self-help extension workers can play an active role, have control over their own community, take part in society, and become more involved in development.

\section{CONCLUSION}

Based on the objectives of the discussion in this study, it can be concluded that, (1) Farmers already know and try organic farming, however, the adoption process is still affected by market access which makes farmers still reluctant to start implementing organic farming; (2) the nature of innovation and extension support are factors that affect the level of interest of farmers; The nature of the candidate (characteristics) and counseling are factors that influence adoption; (3) P4S Agrospora in this case becomes a forum for farmers to learn about the application of organic agriculture but needs to be empowered again for independent extension workers who are able to play the same role as P4S.

\section{RECOMMENDATIONS}

Summary of managerial implications that can be considered based on the research results are as follows: 1 ) increasing the role of research institutions such as the Agricultural Technology Study Center, and extension agencies engaged in the field such as the Agricultural Extension Center; 2) Extension activities should involve more independent extension workers as assistants; 3) Strengthening support for farmer groups, local leaders or leaders as role models, availability of environmentally friendly materials, and easy, inexpensive, and mass access to innovation and information; 4) Increasing market access through promotions, exhibitions, and increasing understanding of the importance of organic rice as a healthy product to consumers and the wider community through social media.

This research cannot be separated from other weaknesses that may be beyond the ability of the author. The suggestions from future research and researchers are as follows: 1) More specific research in areas that are centers of organic rice farming, especially in West 
Java; 2) Adding new variables in order to further deepen the factors that influence the application of organic agriculture such as: millennial farmers, young agricultural entrepreneurs, and linked with several related ministry programs.

\section{REFERENCES}

1. Asta DU, Hubeis AVS, Fatchiya A. 2015. Capacity of ex-coal miner cocoa farmers in Sawahlunto City. Extension Journal. 11(2): 143-158.

2. National Standardization Body. 2016. Indonesian National Standard: Organic Farming System. Jakarta: National Standardization Agency.

3. Burhansyah, Rusli. 2014. Factors Affecting the Adoption of Agricultural Innovations in Vapor and Non-Sweet Gapoktan in West Kalimantan (Case Study: Pontianak and Hedgehog Districts. Agricultural Informatics, 23 (1), June 2014: 65 - 74.

4. Charina, Andriani. 2018. Factors - Factors Affecting Farmers in Applying Standard Operating Procedures (SOP) for Organic Farming Systems in West Bandung Regency, Extension Journal 2018, 14(1); 1-11.

5. Fatchiya A. 2010. Capacity level of fish farmers in managing aquaculture business in a sustainable manner. Extension Journal. 6(1): 11 - 18.

6. Ghozali, Imam, Hengky Latan. 2015. Concepts, Techniques, Applications Using Smart PLS 3.0 for Empirical Research. BP Diponegoro University. Semarang.

7. Gunawan. 2019. Strengthening Adoption and Business Sustainability Organic Rice Farming in Bondowoso and Banyuwangi Regencies, East Java, Dissertation, Bogor, Bogor Agricultural University

8. Haryono, Siswoyo, 2017. SEM Method for Management Research Using AMOS LISREL PLS Luxima Metro Media

9. Hubbard WG, Sandmann LR. 2007. "Using diffusion of innovation concepts for improved program evaluation." Journal of Extension (On-line), 45 (2).

10. IFOAM. 2008. The World of Organic Agriculture - Statistics \& Emerging Trends 2008. Http:/Www.Soel.De/Fachtheraaii Downloads/S_74_L O.pdf.

11. Läpple, D., \& Kelley, H. (2013). Understanding the uptake of organic farming: Accounting for heterogeneities among Irish farmers. Ecological Economics, 88, 11-19.

12. Mardikanto T. 2011. Research methods and evaluation of community empowerment. Surakarta (ID): Sebelas Maret University Press.

13. Prawiranegara D. 2016. Strengthening the role of farmer institutions in increasing the capability of farmers to manage information technology-based innovation: The case of vegetable farmers in the West Java Highlands. Bogor Agricultural University.

14. Purnaningsih N. 2006. Adoption of Vegetable Agribusiness Partnership Innovation Pattern in West Java Province. Dissertation. Bogor: Bogor Agricultural University.

15. Ruhimat S. 2014. Factors for Increasing Farmers' Independence in Community Forest Management: A Case Study in Ranggang Village, South Kalimantan.

16. Saleh, A. et al, 2004. Institutional Analysis of Livestock Rice Integration Systems. Case Study of South Sulawesi and West Java Provinces. Working Papers. Center for the Assessment and Development of Agricultural Technology. Bogor.

17. Sudirman. 2009. Analysis of the Growth Strategy of PT. Main Yummy Foods and Implications For Its Implementation. University of Indonesia. Thesis. Jakarta.

18. Suneeporn Suwanmaneepong; Chanhathai. 2019. Cost and Return Analysis Of Organic And Conventional Rice Production In Chachoengsao Province, Thailand.

19. Soekartawi, 2002, Basic Principles of Marketing Management for Agricultural Products, Theory and Its Application. Jakarta. Raja Grafindo Persada, Jakarta.

20. Syahyuti. 2014. The Strategic Role of Self-Help Extension in the New Paradigm of Indonesian Agricultural Extension. Agro-Economic Research Forum. 32(1):43-58.

21. Van den Ban AW, HS Hawkins. 1999. Agricultural Extension. Canisius Publisher.

22. Zulvera et al, 2014. The behavior of vegetable farmers in responding to the organic vegetable farming system in Agam and Tanah Datar Districts of West Sumatra. International Journal of Sciences: Basic and Applied Research. 16(1): 24-31. 